\section{Estudo cobebate}

em Cestão Planejamento
Revista Estudo \& Debate, Lajeado, v. 26, n. 1, 2019. ISSN 1983-036X DOI: http://dx.doi.org/10.22410/issn.1983-036X.v26ila2019.1940

\title{
COSMOCENE PEDAGOGY: SUSTAINABLE LEARNING IN TIMES OF THE ANTHROPOCENE
}

\author{
Vilmar Alves Pereira ${ }^{1}$
}

\begin{abstract}
This article aims to present some developments and advances in Cosmocene Ecology. Hermeneutical horizon's study in the field of Fundamentals of Environmental Education, it starts from a succinct recovery of the environmental crisis and the demarcation of the Anthropocene Age, later it retakes the main theses of the mentioned ecology and finally demonstrates how this Ecology can be translated in educative principles whose movements and learning can result in the Cosmocene Pedagogy. It is a study that proposes to offer, besides reflections, sustainable principles so that we can educate ourselves to seek a greater guarantee of a decent life based on another concept of development: human development. Philosophical hermeneutics is used as a methodological approach whose interpretative and understanding effort points to the urgent need to reassess the position we have traditionally assumed in the universe. It also points to the need to recognize the knowledge of traditional peoples who have always inhabited the world sustainable development.
\end{abstract}

Keywords: Anthropocene. Pedagogy. Cosmocene. Sustainable.

\section{PEDAGOGIA COSMOCENA: APRENDIZAGENS SUSTENTÁVEIS EM TEMPOS DO ANTROPOCENO}

Resumo: Este artigo tem por objetivo apresentar alguns desdobramentos e avanços da Ecologia Cosmocena. Estudo de horizonte hermenêutico no campo dos Fundamentos da Educação Ambiental parte de uma sucinta recuperação da crise ambiental e da demarcação da Era Antropocena, posteriormente retoma as principais teses da referida ecologia, num segundo momento e finalmente demonstra como essa Ecologia pode ser traduzida em princípios educativos cujos movimentos e aprendizagens podem resultar na Pedagogia Cosmocena. Tratase de um estudo que se propóe oferecer além de reflexóes, princípios sustentáveis para que possamos, além de nos educarmos buscar maior garantia de vida digna baseado em outro conceito de desenvolvimento: o desenvolvimento humano. Utiliza-se como abordagem metodológica a hermenêutica filosófica cujo esforço interpretativo e compreensivo apontam para a necessidade urgente de reavaliarmos a posição que

1 Coordinator of the Program in Environmental Education at FURG. Doctor of Education; Professor and researcher at the Institute of Education and Postgraduate Education Programs (PPGEDU / FURG) and Environmental Education (PPGEA / FURG) - Leader of the Study Group on Fundamentals of Environmental and Popular Education (GEFEAP) of the Federal University of Rio Grande ; Editor-in-chief of Electronic Journal of the Masters in Environmental Education (REMEA) of FURG. Cnpq Productivity Scholar Level 2. 
tradicionalmente assumimos no universo. Também aponta para a necessidade de reconhecimento de saberes dos povos tradicionais que desde sempre já habitavam o mundo de modo sustentável.

Palavras-chave: Antropocena. Pedagogia. Cosmocena. Sustentáveis.

\section{Introduction}

In a previous study on Cosmocene Ecology (PEREIRA, 2016), we started from the already evidenced context of the multiple crises: civilizational crisis (LEFF 2006), meaning crisis (ZOHAR \& MARSHALL, 2012), crisis between science and religion (WILSON, 2008) and, as a consequence, socioenvironmental crisis (BOFF 2012; (2004; LOVELOCK, 2010) and the crisis of paradigm, in which the metaphysical paradigm, which was believed to be a bearer of meaning in the search for humanity's ultimate purposes. Associated with this emerges very strongly the idea of the Anthropocene age that was officially launched by Nobel laureate Paul Crutzen, in 2002, in the journal Nature. In this sense, when scientists assume this terminology, they admit that it is a result of the visible levels of human intervention in the cosmos, especially on Earth. "I am talking about signs that clearly mark the Anthropocene age as a separate interval in geological time. Thus, we need to show that the term is geologically justifiable" (ANTROPOCENO, 2011).

In our understanding there are two movements about the interpretation of that age. The first considers that yes, we are already living in it. The latter is more cautious and still evaluates for a more conclusive result in terms of recognition.

The first ones who have studied this theme, recognizing that we are passing from the Holocene age to the Anthropocene, recognize three great periods in the history of Anthropocene (VALE \& ANDRADE 2011): 1. Formation of the Industrial Age from 1800 to 1945; 2. The great acceleration from 1945 to 2000 (which still continues); 3. The Anthropocene 3.0, in which the movement awakens to the self-consciousness that emerges through the socalled reflexive modernity and the dilemmas of sustainability. It is a consensus among them that we are in a period of irreversible losses with catastrophic changes, leaving more and more signs of global changes altering both the biophysical and socioeconomic conjuncture and the structural dimensions regarding to the functioning of the Earth as a system.

As for the second group, whose members are archaeologists, geochemists, oceanographers and paleontologists, after a meeting in 2016 in Norway, decided to postpone to 2018 the officialization on the beginning of the process of recognition that the earth is already in the anthropocentric age. This information its from the researcher Juliana Ivar do Sul of the Federal University of Rio Grande (FURG), Brazil, a member of the group. While recognizing innumerable evidences and transformations in the layers and rocks as well as on the surface of the seabed by the excessive use of plastic, fragments of artificial materials and the changes that result from them as they do not dilute, Ivar do Sul is cautious: "Proposing a geological age is something very complex (...) we need more scientific evidences." Even though there is no consensus between the two groups and, perceiving the existence of political aspects in the geological period, there is something in common between the two groups: "The environmental transformations provoked by human action are so intense that 
they have already produced indelible marks in the geological record of the planet" (do SUL, 2016).

These are strong elements that contribute to the emergence of the conception of Cosmocene Ecology. Thus, the study sought from eight theses to discuss and problematize: a) The Nature-Humanity relation, claiming a posture of greater recognition of the alterity that integrate nature from the outset, and that consequently are also subject. For, in addition, it suggests a posture of greater humility by overcoming this pretense relationship of humanity-nature domination, where with greater harmony, it is possible for the human being to perceive himself as one more species in this infinite universe. Openness and redefinition of posture are the guiding elements of the proposed relationship; b) From the deceleration of time as a guarantee of life: there emerge deep and dense reflections on the conception of time and on how we are understanding time on the metaphysical horizon. This is given by the fact that we are guided by the modern conception of time. It presents as reflection the concept of presenteeism and the possible anomalies of a humanity that claims to have no time left and that lives the times of acceleration and blocking of all creative capacities. Time is claimed for our affections, our aesthetics, ethics and mysticities. Including time to slow down; c) From the harmony with new wisdoms: attention is drawn to so many wisdoms that have always been there, but in general we do not establish deep syntonies with them. This goes from the knowledge of traditional peoples to the multiple movements in the struggle for life that are occurring all year around the planet. The hermeneutic claim here is one of greater understanding; d) From the care as re-learning vs. uncontrolled consumption: starting from the observation that we are a society that does not take much care of itself, the study points from the genesis of caring as an ontological condition of the human being, passing through different forms of carelessness and suggests the care as a fundamental condition for the sustainability of the universe. It also presents some movements towards care and a culture of peace; e) From the decolonization of the lifeworld: part of (HABERMAS, 2002)'s concept of colonization of the lifeworld and based on Bauman's studies on the impact that social networks have on the consumer generation, especially in the work Consuming Life, that presents reflections on the colonization of our dimension of the linguistic, cultural, affective, subjective structures that suffer this great impact, often losing or creating anomalies, including in our capacity of communication and in the dimensions of dialogues with those who are close; f) For a diverse and unprejudiced world: based on the understanding that the universe has always been biodiverse, plural and multiple, the study denounces all forms of prejudice recognizing that all shrink the expression of life in multiple contexts. It also denounces the epistemological prejudice so reinforced in many academies. For, moreover, this ecology manifests itself as open to all differences transcending the narrowing of boundaries and claiming new ways to be in that infinite universe; g) From the condition of incompleteness: the study starts from the understanding of our ontological vocation which Freirean reading points to this condition of being more. And, in this horizon of being more, discusses and recognizes three controversial strands: the need for a new rapprochement between science and religion (WILSON, 2008); The recognition of the SQ, spiritual coefficient, not as a religion but as a kind of moral compass in the quest to overcome our crisis of meaning (ZOHAR \& MARSHALL, 2012) and the recognition of the existence of the soul. These 
aspects presuppose as a starting point the fact that even though we do not believe in any transcendental-spiritual dimension, we must recognize that for billions of human beings this dimension assumes deep meaning in their lives and ways of being. h) From the place of Environmental Education in Cosmocene Ecology: considers that EE appears a small point in this universe, but that assumes the preponderant role in the sense of resituate us on the paths that we draw. This broad discussion is not disconnected from political and mainly economic interventions. This economy that limits the life forms on the planet. It can serve as an alternative to think of a broader development of the human being than just the narrowness of financial logic: cultural, intellectual, spiritual development of people in their multiple dimensions that can guarantee a decent quality of life. This is what (CAPRA, 2006) calls a qualitative growth. From this scenario emerges the definition of Cosmocene Ecology as: a viable alternative to think about the relationship between living and non-living beings in order that we can ensure a better quality of life on the planet and, perhaps, the universe. It is born in the midst of this scene of despair and fear reinforced by Anthropocene Age and the consequent crises: the fundamentals of EE, of the metaphysical philosophical paradigm, of western's and subject's rationality, the exhaustion of the capitalist system, the logic of profit and consequently the financial crisis, political, social and environmental crisis and, fundamentally, the crisis of existential-ontological sense of space and human sense in the cosmos. Also emerges from a deep hermeneutic intuition that a human repositioning is needed in the cosmos in the broad set of relationships that we establish daily with the universe with which we are connected. Thus, it can also be seen as an expansion of the senses ecology, with the intention of extending our cosmic dimension. (PEREIRA, 2016 a)

\section{Methodological approach Hermeneutics}

As mentioned the study takes as a methodological approach the hermeneutical perspective of (GADAMER, 2002). In this sense the basis of the operation of the hermeneutic circle is its movement of reading the whole to the parts and the parts to the whole. In this process, a text is read several times in a dialectical way between understanding (the synthesis or the non-methodological pole, what the text says) and interpretation (the analysis or the methodological pole, which can be concluded with the text). The author itself is a part of the world and his abstraction from reading is a totalizing theory. In this reflexive process, interpretation and meaning are produced. The great contribution of hermeneutics consists in the interpretation, understanding and amplification of meaning. And to our understanding, that is what we seek to do in this investigation.

\section{The Cosmocene Pedagogy}

When we glimpse this first development of Cosmocene Ecology from a Pedagogy, we point out that each educational principle that emerges here is a result of one of the eight theses that underpin Cosmocene Ecology as we see:

1) The new Nature-Humanity relation - Relational Humanist Learning;

2) From the deceleration of time as a guarantee of life - Learning as a process of valuing life; 
3) From the harmony with new wisdoms - Hermeneutic learning of unacknowledged knowledge;

4) From the care as re-learning vs. uncontrolled consumption - Learning of caring;

5) From the decolonization of the lifeworld - Learning of the Primal Knowledge;

6) For a diverse and unprejudiced world - Learning with Differences;

7) From the condition of incompleteness - Transcendental Learning;

8) From the place of Environmental Education in Cosmocene Ecology - Learning of the Environment altogether.

\section{Relational Humanist Learning}

The human condition is one that needs to be educated. Parting from the Cosmocene Ecology, the Cosmocene Pedagogy claims a process of relearning in the classic humannature relationship. In this sense, unlike some interpretations we see, that we would be denying our human role with our ecology, we suggest this effort of relearning that will contribute significantly in repositioning the anthropocentric perspective towards a more comprehensive view of the cosmos. It is the task of the educator to discuss, problematize and always present the human being in his condition of participant and that at the same time is relational. Thus, the different educational spaces, including home, can guide their practices without giving this exclusive role to humanity, but indicating the possibility of greater integration and why not, of sensitivity so neglected in the classical pedagogies that conceive the educational act as coming from a relationship of knowledge, of people and consequently of nature.

Thus, as just another alterity in this infinite universe, we learn to be more humble and consequently more open to new senses. Humanism stands out here as the ability to relearn and the ability to reposition itself. In this horizon we always learn collectively with the world and with people in an intersubjective perspective.

\section{Learning as a process of valuing life}

We live here the periods marked by intensity of agendas and shortage of experiences with deeper meaning. The denunciation of these intensified processes has already been made by Cosmocene Ecology. When we suggest a relationship of learning that values life, it is considered a pedagogy focused on respect for cognitive, affective, spiritual, aesthetic, biological processes that are not recognized in an order of time and sometimes even violated. We claim with this perspective a possibility of a life that must be learned considering our integral development respecting each stage and each learning situation.

A pedagogy that qualifies learning with necessary times in each subject. Here, perhaps, the introduction of classroom debates and other spaces may be meaningful, about how our learners deal with and conceive time in their agendas and how they relate to the cosmos. Studies and narratives can also be explored to take advantage of discussions about memory by focusing on both recent and antique historical events. It can be learned as some cultures, mainly indigenous, valued time in the sense of living well. Knowledge that allows 
the recognition of the multiple living forms responsible for the balance in the planet and the movements that occur throughout the universe that are not often perceived by humans.

An example of this is the immeasurable migratory phenomena across the planet from one pole to another as the seasons change. There are many species struggling to maintain their lives all the time. This migration is involving humans and non-humans in a rampant struggle for survival. From Antarctic penguins to reindeer in northern Canada. Human migration across the globe of African countries and, more recently, forced migration from eastern Afghanistan to anywhere in the world in the struggle for life.

In our understanding, a life-enhancing pedagogy must recognize and consider these broader phenomena to the nearest events, such as the forms of violence that extinguish life on a daily basis. We read recently another story about the horror of the disaster in Mariana (MG, Brazil) and we are in shock, perplexed by the immeasurable impact that this amount of mud has brought to life on the planet. But more worrying is that in times of so many complaints those responsible for all this still go unpunished. Mariana is the most convincing example that the financial logic predominates over the other dimensions of our life.

In order not to extend ourselves, we then suggest that the value of life should be learned and taught in all formative spaces.

\section{Hermeneutic learning of unacknowledged knowledge}

We learn from the field of philosophy of language and hermeneutical studies that we are not privileged inventors that found and revealed the world to others. In Hermeneutic understanding both world and humans can only be recognized in and by language. This view allows us to recognize that what we have seen has always been there, yet we do not have the openness to perceive by virtue of previous conceptions and the way in which we were educated from homogenizing and monist readings.

Starting from this horizon, being from the moment, in relation to the cosmos, we sometimes shrink and restrict the meaning about the multiplicity so that it can be expressed and understood. There is much wisdom not yet perceived in the infinite universe. We suggest a pedagogy that can provide epistemological and ontological experiences of open understanding. And in this effort of openness perhaps to allow new events, new roles in educational relations and fundamentally new learning, which in turn, will allow that in our educational practices we can express new ways of being.

What is sought here is not iniquity, but recognition. In the environmental sphere, for example, we have for a long time restricted the look at environmental issues with sometimes narrow conservationist practices saying that we were with this conducting Environmental Education at school. In these practices we sometimes prioritized a garden, but we forgot that the EE presupposes, in the first moment, the relationships and socioenvironmental interactions.

The Cosmocene Pedagogy claims this openness of possibilities to many wisdoms that are not yet part of our school curriculum and political decision spaces that we do not recognize or have difficulty doing so. An example of this was in 2015 the great difficulty of discussing diversity and gender in the Brazilian school curriculum in the approvals of the 
Municipal Plans of Education. A great wave of neoconservatism with religious intolerance revealed all its strength and resilience in many municipalities.

The hermeneutical pedagogy should contribute to this comprehensive opening about these phenomena in Brazil on the national political conjuncture. At the moment we write this text we see with great concern some of the guarantees that we yearn for with a lot of struggle being violently threatened. Climate of insecurity and uncertainties. We have no more in the OSPB (Brazilian Social and Political Organization) school curriculum nor EMC (Moral and Civic Education), but its logic has not yet extinguished neoconservative movements that resurge with great vehemence. A cosmocene pedagogy must put all this under discussion and understanding because this has much to do with vital guarantees.

\section{Learning of caring}

When presenting in Cosmocene Ecology how the capitalist system operates from a logic of exclusion and carelessness, we seek, in addition to the denunciation, to promote reflection on the multiple forms of carelessness from issues involving environmental catastrophes, suicides, forced migration as the only alternative in the East and in different countries around the globe and the main one that are the wars for economic and political empowerment. In this perspective, the forms of carelessness take on immeasurable proportions. In all of them we perceive practices of shrinking the guarantee of life.

A Cosmocene Pedagogy points to the possibility of educational practices that recognize that the human being needs care as the first condition. This is what (BOFF, 1999) calls an ontological a priori. That is, it is the care that makes us people. What we are suggesting here is not a curricular discipline, but a proposal of life that, in different educational spaces, values and exercises this previous dimension of the human being. Not as a matter of essence, but as a matter of necessity.

Thus, we see that Environmental Education should be one of the instances that indicate this debate. The forms of carelessness and views, assumes here, the role of blunt criticism ranging from the broader perception of how in traditional communities there were practices of care, even collective, until the establishment of the debate on culture of peace.

A pedagogy that has the humility to recognize that the educational act is a form of care. Also to evaluate that we often allow the logic of carelessness to interfere directly in the field of our biopsychosociaenvirospiritual ${ }^{2}$ dimension.

Thus, care may seem something so simple, but fundamental to guarantee a dignified life as defended by Cosmocene Ecology. The horizon of Post-Metaphysical thinking

2 From now on, I will use the word biopsychosociaenvirospiritual, not yet registered in the dictionaries considering that it expresses a cosmocent understanding of what constitutes humanity. That is why it seeks in a single terminology, to aggregate the biological, psychological, sociological, environmental and spiritual dimensions. It should be noted that its understanding already exists, however in describing it, is most often translated by Biopsychosocial - environmental and spiritual. The change I make here is in the semantic sense of really reinforcing that this understanding in the cosmocene horizon is inseparable. (PEREIRA, 2016a, p.45.) 
recognizes the need for this view that non-violently promotes the development of humanistic potentialities through the relearning of care. Try to reflect on your educational practice, on how much care you have in it. And here it is understood the educational practice as a way of being in and with the world.

\section{Learning of the Primal Knowledge}

The Cosmocene Ecology makes a strong denunciation from the studies of the socalled Critical Theory, particularly (HABERMAS, 2001)'s that the instrumental rationality directed to ends, like empowerment and by the profit interferes in a so forceful way that the system world colonizes the relations of the world of the life. This, in addition to causing innumerable pathologies, also beckons for loss of meaning in the field of primordial relations and knowledge which are in some way the background of our ontological dimension.

We have already pointed out this debate when in the Post-Metaphysical Environmental Rationality we affirm that, in the hermeneutical horizon, there is a recognition of these primeval knowledge and the force of the contexts as fundamental for the understanding of our studies and especially of our life. In a certain way, in waving to this aspect we suggest a Cosmocene Pedagogy that has the recognition of what (FREIRE, 2009) so well pointed out, that the reading of the world precedes the reading of the word. To a certain extent, we stress here that our way of acting and thinking never occurs in a vacuum and are mostly flooded with contexts.

Going a little further, the hermeneutical horizon understands that it is in the dimension of the lifeworld that we manifest our first communicative structures. These in general are linked to the search for our understandings, but also to the affective, emotional structures, our beliefs, aesthetics, our value scale that make up our existential arrangement. To realize that the world system can colonize this dimension is worrying, since this prevents the development of life.

In this way we are not proposing a retrocession, but rather the valorization of this primeval dimension in the sense of not allowing said colonization. The pedagogical perspective that is seen here refers to the possibility that, in the different educational contexts of life, our socio-cultural roots are placed as the first dimension. Another claim is that the educational spaces attend to the strategies that the rationality of failure and disguise has created and that it interfere in the blocking of communicative capacity.

When we raise the discussion of the strong impact that social networks have on our way of being, we are not at all pointing to the retrogression, instead, suggesting a pedagogy that takes advantage of the technological conditions and stimulate the expansion of communication, without forgetting the talking, looking, laughing and listening. (BAUMANN, 2008) alerts us to the risk of the most radical change that occurs in the consumer society where the producer also becomes products.

A pedagogy that recognizes the autochthonous dimensions of the lifeworld with all its structure may also confront the logic of isolation and the blocking of communicative dimension to be promoter and integrator of the new forms without, violating those background knowledge that integrate our first constitution. The challenge to educators is 
always to start from the founding questions about who we are, where we came from, what are our first references, how is the life I live, what are my beliefs, do I have it or not, what are we looking for, what's the point of being here, what do we study for, or what do my parents say about school.

It is up to the educators to develop strategies to talk with their students in order to access their lived world with their previous readings. This is not new, but it can be definitive in the process of teaching.

\section{Learning with Differences}

When in Cosmocene Ecology we discussed the possibility of thinking and experiencing a diverse and unprejudiced world we were not proposing an unreachable metaphysical horizon. We were just questioning, how is possible, in a world so plural and diverse, there can still be thoughts so small and ingrained that they manifest in many ways their prejudices.

We are not specialists in this field of study, however we have had numerous experiences in the University and outside it in the field of affirmative actions that every day reinforce the need for a broader and plural look regarding the recognition of differences in all educational spaces.

When we claim a pedagogy of differences we are fundamentally suggesting a pedagogy that transcends old ways of teaching. A pedagogy open to the recognition that reality is biodiverse. The recognition that in the present context, the homogenizing modes can no longer account for and sense of the plurality that promotes color in all dimensions that surround the cosmos.

We have just knew about a school with a transsexual student. The family knows and does not assume and the school knows and seeks to cover up. We question this educational space about what is the scope of this formation for the life of this child. How many times we are charged in the University, in decision-making spaces, in the sense of justifying the policy for indigenous and quilombola (descendants of Afro-Brazilian slaves who escaped from slave plantations) students who often have coefficient equal to or higher than the others, however, the other students are not requested such justifications. And how many times we have to justify with statistical data proving results on the quota policy as of the adhesion of the law of reserves of vacancies (Law no 12.711/2012). The quota policy enriched the Brazilian public university. How good it is to see the popular classes having access to the university. However we still hear phrases such as "it lowered the level of university".

And here we could bring many stories. However, what we propose with Cosmocene Pedagogy is what (RORTY, 1998) calls redescription. A ability to expand horizons, in the sense of overcoming previous conceptions that are still so deficient, rediscovering, in another way, this world of pre-defined essences. There are already many good practices in this regard with projects that deserve our recognition and respect and are already included in the context of basic education. However, it is necessary that Environmental Education can always contribute to the criticism and the search for this comprehensive enlargement. Educating for the recognition of differences presupposes a great effort and innumerable 
withdrawals because the majority of people had in their formation the same understandings. It is fundamental here the learning of the hermeneutic opening.

\section{Transcendental Learning}

Some friends advised us not to write about it. Just to remember, in Cosmocene Ecology when we present the thesis about of the dimension of incompleteness, we defend and reinforce the importance of the existence of the Spiritual Coefficient, and of the Existence of soul resulting from studies of near death experience at the moment when the brain dies. What we are proposing is that being a man or woman of science I may not even agree with this and with all the other issues that bind us to some transcendence. However, we must respect that for some people, or better for billions of human beings, spiritual matters occupy and maintain great relevance in their way of seeing and living life.

One of the aberrations that we often hear in the institutionalized spaces is to affirm that school or university are secular spaces. We even seek to develop a comprehensive effort on such a manifestation. But deep down we know that these spaces are not secular because the people who constitute these formative spaces are not secular. The majority has, in different ways, something to do with the transcendental.

But how can Cosmocene Pedagogy contribute to this? First, by assuming that we have long outgrown the pedagogical perspective that confused education with instruction. In this perspective the educational act was an external act very close to training. Studies from (ROUSSEAU, 1995), (PESTALOZZI, 1996) and (RIVAIL, 2012), pointed out between the $18^{\text {th }}$ and $19^{\text {th }}$ centuries that the educational act does not mobilize only the external but also the internal abilities. That is why Rousseau speaks of sensitivity and Pestalozzi defended the Pedagogy of love that accesses the heart. Later, Hippolyte Leon Denizard Rivail from his studies, will conclude that being tutor and apprentice possesses, beyond the body, the need of education of its soul in process of continuous learning.

Having, among these references, the Cosmocene Pedagogy, recognizing also that one of the crises of today is the crisis of meaning, it seeks to understand mankind as a biopsychosociaenvirospiritual being. This does not mean in any way the return to indoctrination practices through the castrating religious teaching in many cases and limiter of the human potentialities. It means from scientific findings and lived experiences to place this dimension on the agenda not as a new religion, but as the debate in the search for meaning. There are already advanced studies today in Brazilian medical schools, among others, recognizing in the relationship with patients that to understand their history, this dimension can contribute even to a better quality of life. Due to our previous conceptions and difficulties in accepting the differences, the school still is one of the places that does not promote this debate in the thematic transversality in its curriculum. Of course, this also presupposes formation, but fundamentally the reception of the diverse in the search for meaning. 


\section{Learning of the Environment altogether}

Without denying the specificities of the research fields and the deep respect for the dimensions, I believe that there is a tendency, as a result of modern scientific rationality, to slice Environmental Education. This is so overwhelming that in some debates there is an effort to define whether or not this practice is Environmental Education. In this way, this tension remains as revealing of meaning. We have already pointed out in Cosmocene Ecology how I conceive EE and which place in my understanding it occupies in its horizon.

We would like to emphasize, however, that a Cosmocene Pedagogy should contribute to our understanding of the environment altogether. And we do not use this as a buzzword, but as a sympathetic effort to perceive socio-environmental relationships as an integral part of living and nonliving cycles in this infinite universe. Educating assumes a meaning from our lifeworld, to recognize ourselves also as cosmic beings open to the world. This is not an easy task, because of the difficulty we have in thinking of the environment altogether. At times we feel disconnected from these multiple movements that transcend our everyday in the direction of multiple other possibilities.

Sometimes we cannot deal with our daily life because of the impact that the material agendas, dictated by the logic of consumption and survival, causes on our lives. With great concern I heard someone say that "meditation is something for those who are lazy to work". We wonder how much we lost from the cosmic attunement. The Eastern peoples had great development in their society, for they possess in their culture two great dimensions: high collective conscience and a great respect and practices directed towards the mystical development.

What we are trying to do, is not to put in any formulas, on the contrary, to consider that by the Cosmocene Pedagogy this paradigm of imperialist capitalism does not help for us to understand the environment altogether. That is why it is necessary that we study other Eastern and Latin American civilizations, including Brazilians, that still maintains or preserved some reservations that point to the expansion of meaning and guarantee of life. We see this very often when we visit quilombos and villages. It is the integral education that allow us to recognize as educational all the relations that we maintain in and with the world.

\section{Considerations}

This study demonstrated the need for an ecological horizon pedagogy. The Cosmocene Pedagogy reinforces the need for every educational act to be an ecological act as well. In the eight forms of sustainable learning, the study also reinforces the need for a comprehensive hermeneutic opening on the teaching relationships that transcend the relationships between humans, but are in the direction of deep dialogues that we have already established through language with the world. It is a pedagogy of ontological horizon that beckons to our incompleteness overcoming this fatalistic understanding of the capitalist system that shrinks the forms of life in the realization that in the Anthropocene, human predominance defines an era of disenchantment without utopias. Like the Cosmocene Ecology, this Pedagogy is also an extension of the senses and in this way it is configured as sustainable with possibilities so that we can live better. 


\section{REFERENCES}

Adorno T.W. Palavras e Sinais: Modelos Críticos 2. [Catchwords: Critical Models II]. (M.H. Ruschel, Trans.). Petrópolis: Vozes (Original work published 1969), 1995.

Adorno, T.W. \& Horkheimer, M. (1985). Dialética do Esclarecimento: Fragmentos Filosóficos. [Dialectic of Enlightenment: Philosophical Fragments]. (G.A. de Almeida, Trans.). Rio de Janeiro: Jorge Zahar. (Original work published 1947).

Antropoceno: Cientistas proclamam que estamos no nascimento de uma nova era geológica. [Anthropocene: Scientists proclaim that we are at the birth of a new geological age] (2011, June). EcoDebate. Retrieved from: http://www.ecodebate.com. $\mathrm{br} / 2011 / 06 / 07 / a n t r o p o c e n o-c i e n t i s t a s-p r o c l a m a m-q u e-e s t a m o s-n o-n a s c i m e n t o-d e-u m a-$ nova-era-geological

BAUMAN, Zygmunt. Vida para consumo. [Life for consumption] Rio de Janeiro: Zahar, 2008.

Boff, L. Saber Cuidar: Ética do Humano - Compaixão Pela Terra. [Knowing to Care: Human Ethics - Compassion for the Earth]. Petrópolis: Vozes, 1999.

Boff, L. As Quatro Ecologias: Ambiental, Política e Social, Mental e Integral. [The Four Ecologies: Environmental, Political and Social, Mental and Integral.] Rio de Janeiro: Mar de Idéias, 2012.

Capra, F. O Ponto de Mutaçáo. [The Turning Point]. (Á. Cabral, Trans.). Rio de Janeiro: Cultrix, (Original work published 1982), 2006.

Capra, F. O Tao da Física: Uma Análise Entre os Paralelos Entre a Física Moderna e o Misticismo Oriental. [The Tao of Physics: An Exploration of the Parallels Between Modern Physics and Eastern Mysticism]. Rio de Janeiro: Cultrix. (Original work published (1975), (2011).

FREIRE, Paulo. A importância do ato de ler: em três artigos que se completam. [he importance of the act of reading: in three articles that are completed] 49a ed. Sáo Paulo: Cortez, 2009.

Gadamer, H-G. Verdade e Método. [Truth and Method]. (F.P. Meurer, Trans.). Petrópolis: Vozes, (Original work published 1960), 2002.

Habermas, J. O Discurso Filosófico da Modernidade. [The Philosophical Discourse of Modernity]. (L.S. Repa \& R. Nascimento, Trans.). Lisboa: Dom Quixote, (Original work published 1985), 1990.

Habermas, J. Teoría de la Acción Comunicativa I: Racionalidad de la Acción y Racionalización Social. [The Theory of Communicative Action, Vol. 1: Reason and the 
Rationalization of Society]. (M.J. Redondo, Trans.). Madrid: Taurus. (Original work published 1981), 2001.

Habermas, J. Teoría de la Acción Comunicativa II: Crítica de la Razón Funcionalista. [The Theory of Communicative Action, Volume 2: Lifeworld and System: A Critique of Functionalist Reason]. (M.J. Redondo, Trans.). Madrid: Taurus. (Original work published 1981), 2001.

Habermas, J. Pensamento Pós-metafísico: Estudos Filosóficos. [Postmetaphysical Thinking: Philosophical Essays]. (F.B. Siebeneichler, Trans.). Rio de Janeiro: Tempo Brasileiro. (Original work published 1988), 2002.

Heidegger, M. Ser e tempo. [Being and Time]. (M.S. Cavalcante, Trans.) Petrópolis: Vozes. (Original work published 1927), 1989.

Heidegger, M. Caminos de Bosque. [Off the Beaten Track]. (H.C.A. Leite, Trans.). Madri: Alianza. (Original work published 1977), 1993

INCONTRI, D. Pestalozzi: educação e ética. [Pestalozzi: education and ethics] São Paulo: Editora Scipione, 1996.

INCONTRI, D. Kardec Educador - Textos Pedagógicos de Hippolyte Léon Denizard Rivail. [Kardec Educator - Pedagogical Texts by Hippolyte Léon Denizard Rivail ] São Paulo, Editora Comenius, 2012.

Ivar do Sul, J.A. Uma Nova Época na História Geológica da Terra?. [A New Age in Earth's Geological History]. Ciência Hoje, v. 333, p. 56-57. Retrieved from http://www. cienciahoje.org.br/.2016.

Leff, E. Racionalidade Ambiental: A Reapropriação Social da Natureza. [Environmental Rationality: The Social Reappropriation of Nature]. (L.C. Cabral, Trans.) Rio de Janeiro: Civilização Brasileira. (Original work published 2004), 2006.

Loureiro, C.F.B. Trajetória e Fundamentos da Educação Ambiental. [Trajectory and Fundamentals of Environmental Education]. São Paulo: Cortez, 2004.

Lovelock, J.. Gaia: Alerta Final. [The Vanishing Face of Gaia: A Final Warning: Enjoy It While You Can]. (V.P. Assis, Trans.). Rio de Janeiro: Intrínseca, (Original work published 2009), 2010.

Nietzsche, F. Obras incompletas. [Incomplete Works]. São Paulo: Abril Cultural, 1974.

Pereira, V.A. Ecologia Cosmocena: A Redefinição do Espaço Humano no Cosmos.

[Cosmocene Ecology: The Redefinition of Human Space in the Cosmos]. Juiz de Fora: GARCIA. . (2016a). 
Pereira, V.A. Hermenêutica \& Educação Ambiental no contexto do Pensamento

Pós-Metafísico. [Hermeneutics and Environmental Education in the context of PostMetaphysical Thinking]. Juiz de Fora: GARCIA, (2016b).

Pereira, V.A., Eichenberger, J.C., \& Claro, L.C. A Crise nos Fundamentos da Educaçáo Ambiental: Motivaçóes Para um Pensamento Pós-metafísico. [The Crisis in the Fundamentals of Environmental Education: Motivations for a Post-Metaphysical Thought]. Revista Eletrônica do Mestrado em Educação Ambiental, 32, 2015. pp 177205 ,

Reigota, M. (1994). O que é Educação Ambiental. [What is Environmental Education]. São Paulo: Brasiliense.

ROUSSEAU. J.-J. Emílio ou da educaçáo. [Emílio or education] Trad. Roberto Leal Ferreira. São Paulo: Martins Fontes, 1995.

Rorty, R. A Filosofia e o Espelho da Natureza. [Philosophy and the Mirror of Nature]. (J. Pires, Trans.). Lisboa: Dom Quixote, (Original work published 1979), 1998.

Santos, B.S. A Crítica da Razáo Indolente: contra o desperdício da experiência. [The Critique of Indolent Reason: Against the Waste of Experience]. Porto: Afrontamento, 2000 .

Vale, P.M. \& Andrade, D.C. “Fronteiras planetárias” e limites ao crescimento: Algumas implicaçóes de política econômica. ["Planetary frontiers" and limits to growth: Some implications of economic policy]. Paper presented at the IX Encontro Nacional da ECOECO, Brasília. Retrieved from: http://www.ecoeco.org.br/conteudo/publicacoes/ encontros/ix_en/GT5-112-37-20110609175812.pdf (2011, October).

Wilson, E.O. A Criaçáo: Como Salvar a Vida na Terra. [The Creation: An Appeal to Save Life on Earth]. (I.M. Lando, Trans.). São Paulo: Companhia da Letras. (Original work published 2006), 2008.

Zohar, D \& Marshall, I. QS: Inteligência Espiritual. [SQ: Connecting With Our Spiritual Intelligence.] (R. Jungmann, Trans.). Rio de Janeiro: Viva Livros, (Original work published 2000), 2012. 